\title{
RÉGI ÉPÍTMÉNYEK FÉM ANYAGAI ÉS BIZTONSÁGA
}

\section{METAL MATERIALS AND SAFETY OF OLD BUILDINGS}

\author{
Kopenetz Lajos György ${ }^{1}$, Gobesz Ferdinánd-Zsongor ${ }^{2}$ \\ ${ }^{1,2}$ Kolozsvári Müszaki Egytem, Épitömérnöki Kar, Tartószerkezetmechanikai Tan- \\ szék, Románia, 400020 Kolozsvár, C. Daicoviciu u. 15, 3. em., 305; \\ ${ }^{1}$ Telefon +40-264-401318, ludovic.kopenetz@mecon.utcluj.ro \\ ${ }^{2}$ Telefon: +40-264-401351,go@mecon.utcluj.ro
}

\begin{abstract}
In case of old metal constructions, there is to say where the bearing structure dominates, material issues have a great influence on the behaviour of the construction, in terms of function and safety. Old metal constructions have generally a monumental nature, so preservation, restoration and rehabilitation works are inseparable from material issues. Due to the monumental nature, the material research generally allows only minor damage, so these investigations require the use of special methods.
\end{abstract}

Keywords: structure, monument, safety, metals.

\section{Összefoglalás}

A régi fém építményeknél, vagyis az olyan szerkezeteknél, ahol a tartószerkezet dominál, az anyagi kérdések nagymértékben befolyásolják a szerkezet viselkedését, úgy működés, mint biztonság szempontjából. A régi fém építmények általában müemlék jellegüek, így a konzerválási, restaurálási és rehabilitációs munkák elválaszthatatlanok az anyagi kérdésektől. A müemlék jellegből következik, hogy az anyagi kutatások általában csak elenyésző roncsolást engednek meg, így e kutatások speciális módszerek használatát kérik.

Kulcsszavak: szerkezet, müemlék, biztonság, fémek.

\section{Bevezetés}

A régi építmények állagmegörzéséhez, helyreállításához és megerősítéséhez nem csak statikai mérlegelés, hanem megfelelő anyagismeret is kell. A legszokványosabb gondokat a természetes elévülés okozza.

Köztudott, hogy a vas alapú anyagok korrózióvédelmét nem tudták a régi építményeknél se megoldani (egyebek mellett oly érdekességek is akadtak, mint például a baktériumok által elemésztett vascsövek).

A többi régi építményekhez képest, ezekre az építményekre a nagyméretű kar- csúság jellemző, a tartószerkezetük pedig sok meglepetéssel szolgálhat, így a különböző beavatkozásokat nagy körültekintéssel és mügonddal kell megvalósítani.

Általánosan elfogadott, hogy egy tartószerkezet akkor biztonságos, ha a stabil egyensúlyi helyzetéböl kismértékben kimozdítva visszatér az eredeti állapotába (ahol a rendszer potenciális energiája a legkisebb). Az anyagi kérdések tisztázása nélkül e fém anyagú szerkezetek stabilitási és teherbírási követelményei nem nyújtanak feltétlenül biztonságot azokra a terhelési esetekre, melyek a teljes tönkremenetelt 
vagy a fokozatos összeomlást idézhetik elő. A biztonságot számító mérnökök jellegzetes hibáinak csak egy kis része származik a statikai megfontolásokból, a legnagyobb tévedések az anyagismereti oldalról jelentkeznek.

\section{Anyagjellemzők és vizsgálatok}

A fém anyagú régi építmények vizsgálatakor nagyon fontos a felhasznált anyagok és a létező minőség megállapítása $[1,2]$. A fémeket az elektromos vezetőképesség és a fémes fény különbözteti meg a többi elemtől. A régi építményekhez használt anyagok kutatása és vizsgálata az archeometria segítségével lehetséges, mely által a szerkezeti mérnök a következő információkhoz juthat:

- az építmény müvészettörténeti, régészeti, néprajzi vetületei és készítési technikája;

- a használt anyagok kora és előfordulási helye;
- az építmény és a történelmi, társadalmi kor fejlettségének kapcsolata.

$\mathrm{Az}$ anyagminőségi vizsgálatot föleg laboratóriumi teszteléssel lehet elvégezni, de helyszíni vizsgálatok is lehetségesek. Ez utóbbiakkal lehet megállapítani a különböző terhek okozta alakváltozások nagyságát, a szerkezet dinamikus jellemzőit és válaszát a dinamikus terhelésekre (szél, különbözö rezgések, rezonancia érzékenység), valamint feltérképezni az észlelhető károsodásokat, hibákat (mágneses repedésvizsgálat, penetráló folyadékok, röntgen, ultrahang, defektoszkópia és induktív eljárások segítségével). A laboratóriumi vizsgálatok alapján meg lehet határozni pontosan az anyagokat (mintavétellel, vagy újabban a nélkül) és a fizikai tulajdonságaikat (sürüség, hővezetési képesség, hőtágulási együttható, olvadáspont, rugalmassági együttható, húzószilárdság, folyási határ, szakadási nyúlás, stb.), keménységet, rugalmas vagy rideg viselkedést.

1. táblázat. A régi épitményekben fellelhetö fémek fizikai tulajdonságai és csoportosítása.

\begin{tabular}{|c|c|c|c|c|c|c|c|}
\hline Jellemzők \Fém elem & $\mathrm{Pb}$ & $\mathrm{Zn}$ & Sn & $\mathrm{Cu}$ & $\mathrm{Au}$ & $\mathrm{Ag}$ & $\mathrm{Fe}$ \\
\hline szín & \multicolumn{3}{|c|}{ fehér fémek } & \multicolumn{3}{|c|}{ színes fémek } & fekete \\
\hline $\begin{array}{l}\text { sürüség } \\
(\text { daN/m³) }\end{array}$ & 11300 & 7140 & 7290 & 8860 & 19300 & 10500 & $\begin{array}{c}7250- \\
7800\end{array}$ \\
\hline \multirow{2}{*}{$\begin{array}{l}\text { olvadáspont } \\
\left({ }^{\circ} \mathrm{C}\right)\end{array}$} & 327 & 419 & 232 & 1083 & 1063 & 960 & $\begin{array}{c}1200- \\
1350\end{array}$ \\
\hline & \multicolumn{3}{|c|}{ alacsony } & \multicolumn{3}{|c|}{ közepes } & magas \\
\hline $\begin{array}{l}\text { hőtágulási tényezö } \\
\left(\times 10^{-6} / \text { grad }\right)\end{array}$ & 28,0 & 26,0 & 26,7 & 16,5 & 14,2 & 19,5 & $\begin{array}{c}10,5- \\
11,5\end{array}$ \\
\hline $\begin{array}{l}\text { rugalmassági tényezö } \\
\left(\times 10^{-6} \mathrm{daN} / \mathrm{cm}^{2}\right)\end{array}$ & 0,1050 & 1,3 & 0,415 & 1,2 & 1,0 & 0,77 & $\begin{array}{c}1,69- \\
2,1 \\
\end{array}$ \\
\hline $\begin{array}{l}\text { húzószilárdság } \\
(\text { daN/cm²) }\end{array}$ & $\begin{array}{c}100- \\
300\end{array}$ & $\begin{array}{c}1500- \\
3200\end{array}$ & $\begin{array}{c}200- \\
600\end{array}$ & $\begin{array}{c}1500- \\
4500\end{array}$ & $\begin{array}{c}1200- \\
2200\end{array}$ & $\begin{array}{c}1400- \\
3800 \\
\end{array}$ & $\begin{array}{c}3000- \\
8000\end{array}$ \\
\hline
\end{tabular}

A fém anyagú régi építmények (épületek, hidak, szobrok, stb.) tartószerkezeteiben vas $(\mathrm{Fe})$, réz $(\mathrm{Cu})$ és ötvözetei, cink / horgany (Zn), ón / cín (Sn), ólom (Pb), ritkábban ezüst $(\mathrm{Ag})$, arany $(\mathrm{Au})$ található. Ezek néhány jellemzője az 1. táblázatban van feltüntetve.

\section{A fontosabb fémek alkalmazása a régi építményekben}

A fém alapú anyagokkal kapcsolatban nem ismerjük eléggé elődeink tudását, sok ismeret elavult vagy elveszett mára.

$\mathrm{Az}$ aranyat a legősibb koroktól használják, alacsony olvadási pontja miatt. Tartó- 
szerkezeti elemként ritkán, inkább huzalként vagy borításként alkalmazták (1. ábra). Az ókorban a szerkezeti aranyhuzalt a kikalapált aranyszalag összesodrásával állították elö, a középkorban húzófogót is alkalmaztak. A borításokat aranylemezből kalapálták ki.

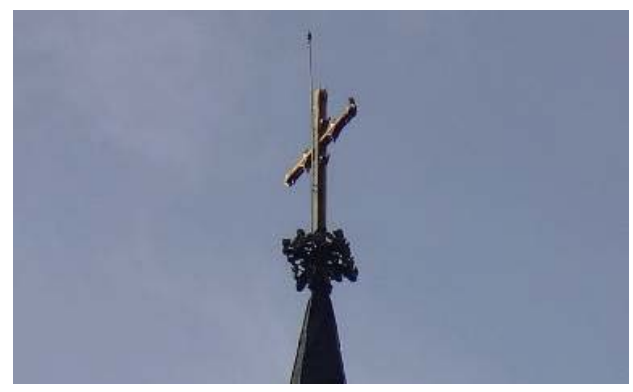

1. ábra. A kolozsvári Szent Mihály templom közel 4 m-es aranyozott keresztje.

Az ezüst nehéz, világos fehér színü fém, jól nyújtható, lágy, kalapálható. Öntését kerülték, mert porózus anyag keletkezik. Tartószerkezeti alkalmazása nagyon ritka, inkább ötvözésre alkalmazták.

A réz az egyik legrégebb használt fém, eleinte inkább kovácsolt formában (különböző vastagságú lemezekként) használták. Vörös színü, jól nyújtható, kalapálható. A levegőn zöld színü réteg (patina) képződik a felületén, mely átmosódva beszínezheti a környező felületeket is. Az öntését elkerülték mivel porózus anyag keletkezik (és az olvadáspontja sem csekély), de ezt ötvözéssel át tudták hidalni. A sárgaréz (tompak, tombak) a római időkben jelent meg, a réz és cink ötvözésével (esetenként ólommal is keverve). Alacsonyabb olvadáspontja miatt öntött tárgyakhoz is használták, de, természetesen, kovácsolt és hidegen formált alakban is sok alkalmazást kapott. A bronz a réz és az ón ötvözete, elég széleskörü alkalmazásra került (lámpatestek és oszlopok, nagyméretü szobrok, díszítések, stb.).

A cink (horgany) kékesfehér színü, csak a felületén oxidálódik vékony rétegben, ami megvédi a korróziótól. Nagyon jól tapad a vasszerkezetekhez, vaslemezekhez és, a korrózió szempontjából, mint pozitív elem, saját tönkremenetele által védi az általa borított vasat (pl. horganyzott lemez). Így nagyon sok szerkezeti díszítésnek az alapanyaga (2. ábra). Az öntvényeket bronzzal bevonva kiváló kőutánzatok készültek.

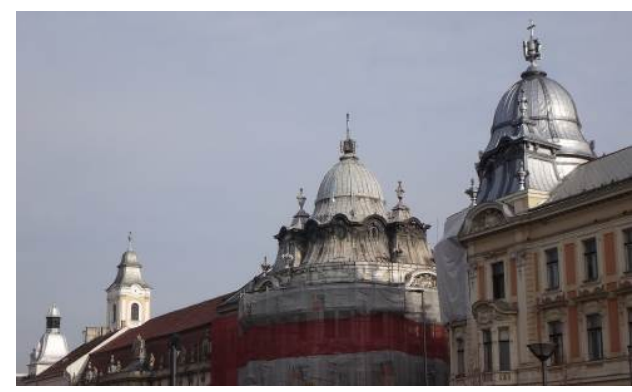

2. ábra. Horganyzott lemezzel borított kupolák Kolozsvár föterén.

Az ón (cin) ezüstfehér színü, igen lágy, nehéz fém, jól nyújtható, kalapálható. Nagy figyelmet kíván a fehér ón, mely $13,2{ }^{\circ} \mathrm{C}$ alatt szürke ónná módosul és porrá alakul (ónpestis). Nagyon jól tapad a vasszerkezetekhez, vaslemezhez (öntött vaslemez, vagy fehér lemez) és ezeket védi (mint pozitív elem) a korróziótól, akárcsak a cink.

Az ólom kékesszürke színü, nehéz lágy fém. A felületen oxidálódik vékony rétegben, ami megvédi a korróziótól és a híg savaktól (kénsav, sósav), kivéve a salétromsavat $\left(\mathrm{HNO}_{3}\right)$. Könnyen nyújtható közönséges hőmérsékleten, de az olvadási pontja körül igen merevvé válik. Leginkább lemezek, huzalok, csövek, szigetelések anyagaként szerepel, valamint vánkos lemez, öntöttvas, kő és fa oszlopok támaszkodási pontjain.

A vas ezüst fehér színü, nehéz fém, mely levegőn rozsdásodik, korrodálódik és védelem hiányában az egész vasszerkezet elpusztulhat (3. ábra). A rozsdásodás a felületén kezdődik (barna színű oxid-hidroxid réteg képződik, mely nem össze-függő, így nem védi meg a további oxidációtól) és befelé haladva duzzadást is okozhat. 


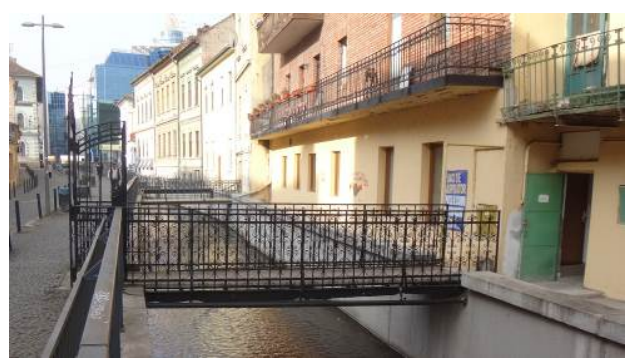

3. ábra. Vas híd (kovácsoltvas karfa és kapu, rozsdától elemésztett acélgerenda alul csővel erösitve) és erkélyek a kolozsvári Malom-árok felett.

A régi építményeknél nyersvas (fehér vagy szürke), öntöttvas (folyasztottvas, folytvas), kovácsoltvas (hegeszvas, kavartvas), vagy acél (folytacél) formájában található leginkább. A nyersvas 2,3-6\% szenet tartalmaz, ahol a szén két féle formában jelentkezhet (vas-karbidként a fehér nyersvasban, szén grafitként a szürke nyersvasban). Az öntöttvasat a nyersvas megolvasztásával és formába öntésével kapják. A fehér nyersvasból kapott öntöttvas kemény (nem fogja a reszelő), rideg, nem nyújtható és nehezen olvad. Azok a régi építmények, ahol ebből az anyagból van a tartószerkezet, nagyon nagy figyelmet igényelnek a nagy merevség és a duktilitás teljes hiánya miatt (a kihajlás lehetetlen és a földrengés okozta hirtelen lökésekre nem tud válaszolni a szerkezet). A szürke nyersvasból készült öntöttvas lágyabb (reszelhető, fúrható) és könnyebben olvad. A kovácsoltvas széntartalma kicsi (0,2\%-nál kisebb), kovácsolható és hegeszthető lágy vas. Az acél széntartalma 1,5-2\% (vas-karbid alakjában), kovácsolható és hegeszthető.

\section{Következtetések}

A régi építményekben található fém anyagok tulajdonságainak az ismerete és kutatása nem csak a szerkezeti hibák feltá- rása során segít, hanem a hibák elhárítására tett javaslatok kidolgozásában is. Habár a tartószerkezetekre vonatkozó szabályok időnként változnak, az építmények elegendő hordképességgel és tartóssággal kel bírjanak. Minden tartószerkezet hordképessége és tartóssága elsősorban a felhasznált szerkezeti anyag függvénye, ezért a tartószerkezeti szakértőnek a véleménye, valamint az építmény biztonságos és okszerü használatára vonatkozó elöírásai jelentik az egyedüli járható utat. A szakértőnek meg kell vizsgálnia, hogy a tartószerkezet képese a formai összefüggések érzékelhető változása nélkül biztonságosan levezetni a terheléseket a talajra. Az igénybevételek számításánál oda kell figyelni, hogy a rugalmassági határon ne haladjanak túl a szerkezeti részek, mert a fém anyagú szerkezeteknél a rugalmassági határ átlépése szorosan összefügg a fáradási tönkremenetellel (az avultság miatt javasolható, hogy a határfeszültségeknek csak a fél értékével végezzék a számításokat).

A mai tervezési filozófia a biztonságos tönkremenetel elvén alapszik, tehát megengedi a helyi károsodást, de nem fogadja el a progresszív, vagy teljes összeomlást. Ezt csak nagy egyszerüsítéssel lehet a régi szerkezetek esetében alkalmazni, nem elég a statikus és dinamikus hatások okozta szilárdsági, alakváltozási és elmozdulási értékek kiszámítása, hanem nagyon fontos ezeknek a hatásoknak a csökkentése.

\section{Szakirodalmi hivatkozások}

[1] Riederer, J.: Kunstwerke chemisch betrachtet. Materialen, Analysen, Altersbestimmung, Springer Verlag, Berlin, Heidelberg, New York, 1981.

[2] Kopenetz, L. G.: Gondolatok statikusoknak, Kriterion Kiadó, Kolozsvár, 2006. 